\title{
Persepsi Anak terhadap Kedekatan Orang Tua dengan Kecerdasan Emosi Remaja
}

\author{
Ayu Metri Wulandari ${ }^{1)}$ \\ Fakultas Psikologi Universitas Yudharta Pauruan \\ E-mail: ayumetriwulandari2395@gmail.com \\ Nathania Bayu Astrella ${ }^{2)}$ \\ Fakultas Psikologi Universitas Yudharta Pauruan \\ E-mail: nb.astrella@gmail.com
}

\begin{abstract}
Behaviors that show failure to manage a relationship and interact with the environment and failure to manage and control emotions more often in youth, such as rudeness, abuse of others, even self-injury. One factor that affects the emotional intelligence of a youth is the family environment especially a parent, the teen's perception of a parent's closeness that affects attitudes, views, assessments, and the quality of relationships that grow. This closeness is made by parents and youth essential to shaping emotional intelligence, as parental experience becomes the basis of emotional learning to internalize life. The purpose of this study is to determine if there is a connection between a child's perception of parental closeness and the emotional intelligence of a teen. The population used was 475 high school students, sampling taken with sampling techniques of $21 \%$ a total of 100 students. Coefficient validity of the scale of a youth's emotional intelligence is acquired between 0.3307 to 0.6120 and some of its religious coefficiencies. 7391. The child's perception of a parent's closeness scale is between 0.3726 and 0.5912 and the religious coefficiencies of 0.8307 . The correlation test shows rxy $=0.4007$ with are table $1 \%=0.256$ and freg $=18,7464$ with table $1 \%=6.63$, the more positive the child's perception of parent proximity, the higher the emotional intelligence.
\end{abstract}

Keywords: emotional intelligence, perception, parental closeness

Abstrak. Perilaku yang menunjukkan gagalnya pengelolahan hubungan dan interaksi dengan lingkungan serta kegagalan dalam mengelola dan mengendalikan emosi semakin marak terjadi pada remaja, seperti bertindak kasar, menganiaya orang lain, bahkan menyakiti diri sendiri . Salah satu faktor yang mempengaruhi kecerdasan emosi remaja adalah lingkungan keluarga terutama orang tua, dimana persepsi remaja terhadap kedekatan orang tua mempengaruhi sikap, pandangan, penilaian, serta mempengaruhi kualitas hubungan yang berkembang. Kedekatan yang diciptakan orang tua dengan remaja sangat dibutuhkan membentuk kecerdasan emosi, karena pengalaman orang tua menjadi modal dasar pembelajaran emosi untuk menginternalisasikan kedalam kehidupan. Tujuan penelitian ini untuk mengetahui ada tidaknya hubungan antara persepsi anak terhadap kedekatan orang tua dengan kecerdasan emosi remaja. Populasi yang digunakan berjumlah 475 siswa SMP, pengambilan sampel dengan teknik kuota sampling sebanyak $21 \%$ berjumlah 100 siswa. 
Koefisien validitas skala kecerdasan emosi remaja diperoleh antara 0,3307 sampai 0,6120 dan koefisien reliabilitas sebesar 0,7391. Skala persepsi anak terhadap kedekatan orang tua diperoleh antara 0,3726 sampai 0,5912 dan koefisien reliabilitas sebesar 0,8307. Hasil uji kolerasi menunjukkan $\mathrm{r}_{\mathrm{xy}}=0,4007$ dengan $\mathrm{r}$ tabel $1 \%=0,256$ dan $\mathrm{F}_{\mathrm{reg}}=$ 18,7464 dengan $\mathrm{F}$ tabel $1 \%=6,63$, maka semakin positif persepsi anak terhadap kedekatan orang tua, maka semakin tinggi kecerdasan emosi yang dimiliki remaja.

Kata kunci: Kecerdasan emosi, Persepsi, Kedekatan orang tua

Melihat fenomena yang seringkali terjadi sekarang ini, semakin banyak kasus-kasus kriminal di media massa yang melibatkan remaja, di antaranya: pada 16 November 2015, perilaku remaja yang bertindak kasar atau menganiaya orang lain, dan juga tidak jarang untuk menyakiti dirinya sendiri karena sangat emosionalnya, seperti contoh yang terjadi pada salah satu wibesite (SINDOnews, 2015), Tri Yulianto mengemukakan seorang gadis remaja berusia 15 tahun ditemukan tewas dalam posisi leher tergantung, hasil keterangan yang di peroleh dari saksi mata bahwasanya hal tersebut terjadi setelah korban baru saja diputus oleh sang kekasih pujaan hati. Kemudian (TRIBUN-Medan.com, BINJAI), M Azhari Tanjung melaporkan mengenai beredarnya video siswi SMPN 4 Binjai yang berinisial RK pada saat membully siswa lain. Menurut sumber Tribun, RK dibesarkan dari keluarga yang kurang harmonis karena kedua orang tuanya bercerai (7/9/2015). Dari data kepolisian ada 33 kasus pencurian dengan kekerasan dijalanan atau begal $70 \%$ pelaku begal dilakukan oleh remaja atau dibawah usia 17 tahun. Fenomena tersebut menunjukkan bahwa individu gagal dalam mengelola hubungan dan interaksinya dengan lingkungan sekitar serta gagal dalam mengelola dan mengendalikan emosi pribadi yang dimiliki oleh dirinya.

Berdasarkan pakar psikologi perkembangan yakni, Jean Piaget, remaja perlu melakukan aksi tertentu atas lingkunganya untuk dapat mengembangkan cara pandang yang kompleks dan cerdas atas setiap pengalamanya. Salah satu bagian dari tahap perkembangan adalah 
kecerdasan emosi serta ditambah oleh Golema (2016) Kecakapan individu dalam menyadari emosinya, mengelola emosi, memanfaatkan emosi untuk memotivasi diri kehal yang baik dan memahami perasaan orang lain menjadi tolak ukur kecerdasan emosi. Menurut M Louise, (dalam Epa, 2013) kedekatan antara anak dengan orang tua yang dibangun sejak dini membuat anak terbuka dalam hal apapun kepada ayah atau ibu sehingga anak dapat mengelolah emosinya.

Hermasanti, (2009) juga mengatakan agar remaja dapat melewati masa strorm an stress dengan baik, dapat bertahan dalam kehidupan bermasayarakat dengan menjadi anggota masyarakat yang memiliki kemampuan bersosialisasi, mengembangkan diri dengan lingkungan yang baru, remaja hendaknya memiliki kecerdasan emosi. Banyak penelitian yang sudah membuktikan pentingnya seseorang memiliki kecerdasan emosional.dalam hal ini, Hal tersebut kemukakan oleh Reni (2008) remaja yang memiliki kecerdasan emosi yang baik merupakan remaja yang dapat memahami, mengelola dan mengendalikan emosinya. Oleh sebab itu, apabila remaja memiliki kecerdasan emosi yang baik akan memiliki keterampilan hubungan interpersonal dan intrapersonal yang baik. Begitupun sebaliknya, apabila remaja memiliki kondisi kecerdasan emosi yang kurang baik, hal tersebut akan mengakibatkan remaja kurang berusaha memahami orang lain, sehingga membuat remaja cenderung lebih berorientasi pada dirinya sendiri. Goleman (2016) mengemukakan pendapat mengenai faktor-faktor yang dapat mempengaruhi perkembangan kecerdasan emosi remaja salah satunya adalah lingkungan keluarga. Lingkungan keluarga merupakan tempat pendidikan pertama bagi seorang anak dalam mempelajari emosi, dan hal ini dapat berkembang hingga individu beranjak dewasa. Lingkungan keluarga yang sangat dekat dengan anak merupakan orang tua. Keterlibatan orang tua dalam memberikan bimbingan serta arahan bagi anak akan menentukan keberhasilan anak pada tahap 
selanjutnya termasuk perkembangan emosinya.

Kecerdasan Emosi Remaja

Goleman (2014) mengatakan bahwa kecerdasan emosional merupakan kemampuan emosi yang meliputi kemampuan untuk mengendalikan diri, memiliki daya tahan ketika menghadapi suatu masalah, mampu mengendalikan impuls, memotivasi diri, mampu mengatur suasana hati, kemampuan berempati dan membina hubungan dengan orang lain. Salovey (Goleman, 2016) mengatakan kecerdasan emosi meliputi kemampuan mengenali emosi diri, kemampuan mengelola emosi diri, memotivasi diri sendiri, kemampuan mengenali emosi orang lain dan kemampuan membina hubungan baik dengan orang lain. Goleman (2016) menyatakan kecerdasan emosi adalah kemampuan untuk memotivasi diri sendiri dan bertahan terrhadap frustasi; mengendalikan dorongan hati dan tidak melebih-lebihkan kesenangan; mengatur suasana hati dan menjaga agar beban stress tidak melumpuhkan kemampuan berfikir, berempati dan berdoa.

Beberapa aspek-aspek dalam kecerdasan emosi yaitu:

1. Pengenalan diri (Self Awareness)

Kecerdasan emosional ditandai dengan kemampuan seseorang dalam mengenali perasaan yang terjadi dalam dirinya sendiri, dimana hal ini seringkali disebut dengan kesadaran diri. Lantas ketidakmampuan seseorang untuk memahami perasaannya sendiri, justru akan membuat individu berada dalam kekuasaan perasaan yang cenderung tidak menentu da berubah-ubah. Orang-orang yang memiliki keyakinan lebih tentang perasaannya dapat mengarahkan kehidupannya dengan lebih baik. Individu tersebut memiliki pengertian dan merasa mantap dalam mengambil keputusan terhadap kehidupan pribadinya.

2. Mengelola Emosi atau pengendalian diri (Self Regulation)

Dari kesadaran diri yang tepat, seseorang dapat memahami serta mengelola perasaan agar dapat terungkap secara baik. Mengelola 
perasaan secara tepat merupakan kemampuan yang diperlukan untuk mengendalikan diri. Orang-orang yang kurang dalam kemampuan ini terus menerus berada dalam perasaan menderita,sedangkan mereka yang dapat mengatasinya dapat merasa segar kembali jauh dari kemunduran dan ganggguan dalam kehidupan.

3. Memotivasi Diri Sendiri (Motivating Ownself)

Mengatur emosi sebagai alat untuk mencapai tujuan adalah hal yang mendasar untuk dapat memberikan perhatian, memotivasi diri dan menguasaidiri, serta mengembangkan kreativitas. Orangorang yang memiliki ketrampilan ini cenderung lebih produktif dan efektif dalam melakukan berbagai aktivitas. Kemampuan memotivasi diri yang dimiliki individu akan mendorongnya untuk cenderung memiliki pandangan yang positif dalam menilai segala sesuatu yang terjadi dalam dirinya.

\section{Mengenali Emosi Orang Lain/} Empati (Emphaty)
Empati atau mengenal emosi orang lain dibangun berdasarkan pada kesadaran diri. Jika seseorang terbuka pada emosi sendiri, maka dapat dipastikan bahwa ia akan terampil membaca perasaan orang lain.

5. Membina Hubungan atau Keterampilan Sosial (Social Skills) Seni membina hubungan, sebagian besar merupakan ketrampilan mengelola emosi orang lain. Orang-orang yang unggul dalam ketrampilan ini dapat melakukan segala sesuatu dengan baik. Mereka dapat melakukan interaksi dengan orang lain dengan lancar dalam pergaulan sosial. Maka dapat dikatakan bahwa seni dalam membina hubungan dengan orang lain merupakan keterampilan sosial yang mendukung keberhasilan dalam pergaulan dengan orang lain.

$\begin{array}{rr}\text { Sedangkan } & \text { faktor yang } \\ \text { mempengaruhi } & \text { perkembangan } \\ \text { kecerdasan emosi menurut Goleman }\end{array}$
(2014) adalah:

1. Lingkungan keluarga 
Lingkungan keluarga adalah sekolah pertama dalam mempelajari emosi bagi seorang anak. Dalam hal tersebut orang tua berperan penting dalam membentuk emosi yang dimiliki anak. Anak dapat mengidentifikasi perilaku orang tua kemudian diinternalisasikan akhirnya menjadi bagian dalam kepribadian anak. Kehidupan emosi yang dibangun di dalam keluarga sangat berguna bagi anak kelak, bagaimana anak dapat cerdas secara emosional.

\section{Lingkungan non keluarga}

Lingkungan non keluarga dalam hal ini adalah lingkungan masyarakat dan juga lingkungan pendidikan yang dianggap bertanggung jawab terhadap perkembangan kecerdasan emosi. Pergaulan dengan teman sebaya, guru, seta masyarakat luas.

\section{Otak}

Organ yang paling penting yang ada pada diri manusia adalah otak. Dalam hal ini otak dapat mempengaruhi dan mengontrol seluruh kerja tubuh. Struktur otak manusia yang berperan dalam kecerdasan emosi individu diantaranya korteks dan sistem limbik. Korteks berfungsi membuat seseorang berada di puncak tangga evalusi. Korteks berperan penting dalam memahami kecerdasan emosi serta dalam memahami sesuatu secara mendalam, menganalisis mengapa kita mengalami perasaan tertentu, selanjutnya berbuat sesuatu untuk mengatasinya. Korteks khususnya lobus frontalis dapat bertindak sebagai saklar peredam yang memberi arti terhadap situasi emosi sebelum berbuat sesuatu. Sedangkan sistem limbik yang sering disebut sebagai bagian emosi yang letaknya jauh dalam hemisfer otak besar terutama bertanggung jawab atas pengaturan emosi dan impuls. Sistem limbik meliputi hippocampus, tempat berlangsungnya proses pembelajaran emosi. Selain itu ada amigdala yang dipandang sebagai pusat pengendalian emosi pada otak.

\section{Remaja}

Dalam hal ini beberapa ahli telah mendefinisikan mengenai pengertian remaja. Dalam bahasa latin menurut 
Golinko dalam Jahja (2011) remaja berasal dari kata adolesence yang artinya tumbuh menjadi dewasa, masa remaja dimulai saat datangnya pubertas pada usia 11 hingga 14 tahun dan berakhir pada usia 18 tahun dengan hal tersebut remaja mengalami perubahan dalam sistem kerja hormon di dalam tubuhnya dan hal ini memberi dampak, baik berupa fisik dan psikis terutama emosi.

Persepsi Anak Terhadap Kedekatan Orang Tua

Persepsi disebut sebagai proses diterimanya rangsang hingga timbulnya pengertian. Persepsi merupakan pengalaman tentang objek, peristiwa atau hubungan yang diperoleh dengan menyimpulkan informasi dan menyampaikan pesan. Adapun definisi menurut Rakhmat dalam Fatimah (2010) persepsi merupakan penafsiran stimulus yang telah ada di dalam otak. Bimo Walgito dalam Safitri (2012) mengemukakan pendapat tentang persepsi yaitu suatu proses yang dilakukan oleh proses pengindraan. Stimulus diterima oleh individu melalui alat indra atau juga disebut proses sensori kemudian stimulus tersebut diteruskan yang merupakan proses persepsi. Chaplin dalam Charis (2013) menambahkan proses perceptual dimulai dengan perhatian, yaitu merupakan proses pengamatan selektif. Faktor-faktor perangsang yang penting dalam perbuatan memperhatikan ini ialah perubahan, intensitas, kontras dan jarak. Faktor yang penting ialah minat, kepentingan dan kebiasaan memperhatikan yang telah dipelajari. Sehingga dapat dikatakan persepsi adalah aktifitas menginterpretasikan suatu obyek atau stimulus tertentu kemudian memaknai arti obyek tersebut.

Adapun persepsi anak terhadap kedekatan orang tua yang dimaksud dalam penelitian ini menurut Hurlock dalam Fatimah (2010) perlakuan orang tua terhadap seorang anak mempengaruhi bagaimana anak tersebut memandang, menilai, dan mempengaruhi sikap anak tersebut terhadap orang tua serta mempengaruhi kualitas hubungan yang berkembangan diantara mereka. Bentuk kedekatan yang di berikan 
orang tua terhadap anak dalam kedudukanya sebagai pendidik agar pengalaman belajar anak pada lingkunganya untuk dapat mengembangkan cara pandang yang kompleks dan cerdas atas setiap pengalamanya. Dalam hal ini, semua proses belajar selalu dimulai dengan persepsi, yaitu setelah anak menerima stimulus atau suatu pola stimuli dari lingkunganya. Persepsi dianggap sebagai tingkat awal struktur kognitif seseorang.

Menurut Filley, Haise, dan Karl, Dirjen Dikti, dalam Safitri (2012) ada tiga komponen utama dalam persepsi. Ketiga komponen itu sebagai berikut: 1. Seleksi merupakan proses psikologis yang sangat erat dengan pengamatan atau stimulus yang diterima dari luar. Rangsangan (stimulus) dari luar yang mencapai indera tidak terbatas, baik mengenai jenis, maupun mengenai intensitasnya. Namun sebagian kecil stimulus yang mencapai kesadaran kita, karena adanya proses penyaringan, disamping faktor intensitas bentuk kedekatan yang diberikan.
2. Interpretasi yaitu proses mengorganisasikan informasi sehingga mempunyai arti bagi seseorang, interpretasi tergantung kepada berbagai faktor, seperti pengalaman, sistem nilai, motivasi, kepribadian dan kecerdasan.

3. Reaksi adalah interpretasi dari persepsi kemudian diterjemahkan dalam bentuk tingkah laku.

Kemudian untuk membentuk persepsi anak terhadap kedekatan orang tua maka tiga komponen tersebut dihubungkan dengan stimulus yang berasal dari kedekatan orang tua. Menurut Hafidz, 1997 (dalam Sholikah, 2011) kedekatan mengandung dua pengertian, yaitu kedekatan dari segi fisik dan kedekatan dari segi psikologis (emosi) diantaranya:

1. Kedekatan Fisik

Kedekatan dalam hal ini hanya melibatkan hubungan fisik luar atau badan bagian luar antara orang tua dengan anak. Kedekatan fisik dapat memberikan makna yang mendalam bagi anak. Sentuhan lembut yang diberikan orang tua pada bagian tubuh 
anak, merupakan metode tersendiri yang secara tidak langsung akan menimbulkan rasa percaya diri dan rasa aman pada anak. Hal tersebut jika dilakukan orang tua secara berkesinambungan kepada anaknya, maka keduanya akan saling menyayangi dengan tanpa syarat.

\section{Kedekatan Emosi}

Kedekatan emosi antara orang tua dengan anak dapat dimulai dengan membangun kedekatan secara fisik, yang seharusnya telah terbangun sejak anak usia dini. Dengan kedekatan, orang akan bisa memberikan pengaruh yang kuat dan mendalam. Selain itu kedekatan mampu mewarnai, mempersuasif, serta menanamkan nilai positif pada orang lain. Secara fitrah hubungan keluarga (orang tua - anak) adalah hubungan 'terdekat' yang melibatkan emosi terdalam dalam diri manusia. Adapun bentuk kedekatan emosi, antara lain:

a. Menjadikan anak sebagai teman

Menjadikan anak sebagai teman adalah hal yang sangat penting dalam pembentukan jiwa anak, karena dua orang teman dapat dengan mudah mengambil pelajaran antara satu dengan yang lainya. Tentu saja dengan tidak mengurangi rasa hormat anak kepada orang tua, dan sebaliknya orang tua harus memilah dan memilih dalam bertindak dan bertutur kata.

b. Memberikan dorongan semangat kepada anak untuk maju

Dorongan yang maksimal akan memberi sugesti kepada anak untuk benar-benar maju dalam segala bidang. Dalam hal ini orang tua harus berperan aktif untuk menuntun dan mengarahkan anak agar tetap berfikit maju dan berperilaku baik.

c. Menanamkan rasa percaya diri pada anak

Memperkenalkan anak dengan lingkungan sekitar dan bersosialisasi dengan orang lain merupakan salah satu bentuk penanaman rasa percaya diri pada anak. Pengalaman yang di dapat oleh anak dari hasil interaksi dengan orang lain dapat menjadi motivasi untuk lebih percaya diri dalam membangun hubungan baru dengan orang lain pada pertemanan atau interaksi berikutnya. 
d. Menyeru dengan lemah lembut dalam mendidik anak

Anak akan lebih merespon secara cepat apabila kita memanggil dengan frekuensi suara rendah dan lembut di bandingkan dengan suara yang keras dan kasar.

e. Menghargai dan mengerti keberadaan anak

Orang tua yang menghargai anaknya, tidak memaksakan nilai-nilai yang dianut, tetapi memperlakukan anak dengan baik dan tidak selalu memposisikan anak sabagai anak kecil yang hanya bisa diberi tanpa memberikan kesempatan kepada anak untuk berpendapat dan berkreasi. Kalaupun sedang bicara dengan anak, posisikan dirinya sebagai sosok yang dihargai dengan tanpa meremehkan pendapat atau kreasi anak. Dalam beberapa hal tertentu, terkadang anak lebih mengetahui dan memahami dibandingkan dengan orang tuanya. jadi ada baiknya orang tua menghargai dan mendengarkan anaknya serta meluruskannya jika anak berbuat atau berpendapat yang salah. Utamakan memberi pujian kepada anak daripada mencela perbuatannya, karena dengan pujian itu rasa percaya diri pada anak akan semakin berkembang.

Berdasarkan paparan Edward R. Christopherson (dalam Kurasi, 2015) sebuah pelukan jauh lebih efektif dari pada pujian atau ucapan sayang karena membuat anak merasa dicintai dan dihargai. Dalam hal ini apabila orangtua dapat menciptakan kedekatan dengan memberikan pelukan terhadap anak-anaknya hal tersebut akan menjadikan anak merasa dicintai dan dihargai sehingga hal tersebut dapat berdampak positif terhadap persepsinya mengenai kedekatan orang tuanya, sehingga berdampak baik pada kecerdasan emosinya, seperti menjadi lebih mampu mengendalikan emosinya saat menghadapi kesulitan atau masalah. Feeney, J. Noller, dan Patty 1993 (dalam Asyava, 2011) mengatakan bahwa individu yang memiliki orang tua yang tidak merespon atau cenderung menolak ketika anak mendekat untuk mencari kenyamanan atau perlindungan hal tersebut cenderung membentuk persepsi 
negatif anak terhadap kedekatan orang tuanya, sehingga membuat anak ketika tumbuh menjadi remaja, anak akan menerima dan terlibat dalam pergaulan bebas.

Sholikah (2011) mengatakan bahwa, sikap keterbukaan antara orang tua dengan anak sangat diharapkan sehingga keduanya merasa dekat dan merasa nyaman, baik jasmani maupun rohaninya. Sikap orang tua yang sedemikian ini berpengaruh besar terhadap pembentukan persepsi anak terhadap kedekatan orang tuanya dan watak anak-anaknya. Hubungan yang setia, sekata, dan akrab tersebut mengakibatkan di antara keduanya saling mengaku, menyadari, merelakan, sehingga terjalin hubungan saling terbuka, saling menghargai serta saling hormat menghormati. Dengan adanya persepsi anak terhadap kedekatan orang tua yang positif seperti itu akan mempengaruhi rasa percaya diri pada anak dan berdampak positif dengan kecerdasan emosinya.

Dari penjelasan di atas sangat jelas bahwa kedekatan orang tua dan anak mempengaruhi persepsi anak terhadap kedekatan orang tuanya, hal tersebut didukung oleh pendapat Rahmad, 2001 (dalam Fatimah, 2010) persepsi terhadap perilaku atau kedekatan orang tua merupakan cara pandang anak terhadap bentuk kedekatan orang tua yang diterimanya, sehingga apabila seorang anak yang mempersepsikan kedekatan orang tuanya secara positif menurut pengalaman yang diterima anak, maka hal ini cenderung dapat menciptakan kecerdasan emosi yang tinggi. Sehingga dalam hal ini, persepsi anak terhadap kedekatan orang tuanya juga merupakan salah satu faktor yang bisa mempengaruhi kecerdasan emosi. Dalam sebuah penelitian juga mengatakan bahwa kedekatan orang tua dan anak dapat mempengaruhi perkembangan mental anak yakni persepsi anak terhadap pola kedekatan orang tuanya, hal ini didukung dari sebuah penelitian yang menunjukkan bahwa melalui rangsangan langsung seperti pelukan, mengajak bicara, dan bermain pada anak yang dilakukan orang tua dapat merangsang persepsi anak terhadap pengetahuan sosialnya, 
dalam artian yang lebih jelas, bahwa persepsi anak terhadap kedekatan orang tua yang positif mampu memberikan sumbangan nilai positif terhadap kecerdasan emosi anak menjadikan lebih percaya diri, memiliki rasa empati dan mudah bersosialisasi. Sehingga persepsi anak mengenai kedekatan orang tua memberikan sumbangan dalam membentuk kecerdasan emosi yang dimiliki remaja. Hal ini pada akhirnya akan memberikan pengaruh pada peningkatan kecerdasan emosi.

Berdasarkan uraian teoritik yang telah dikemukakan, maka hipotesis penelitian ini adalah ada hubungan antara persepsi anak terhadap kedekatan orangtua dengan kecerdasan emosi remaja.

\section{Metode}

Rancangan Penelitian

Penelitian ini digunakan penelitian kuantitatif. Jenis penelitian yang digunakan dalam penelitian kali ini adalah korelasional, disebut korelasional karena untuk mendekteksi sejauh mana variasivariasi pada satu faktor berkaitan dengan variasi-variasi pada satu atau lebih faktor lain berdasarkan pada koefisien korelasi (Suryabrata, 2013).

\section{Populasi dan Sampel}

Populasi yang diteliti adalah remaja di SMP Negeri 2 Sukorejo yang berjumlah \pm 475 remaja. Arikunto (2006) Apabila subyek kurang dari 100 lebih baik diambil semua, akan tetapi apabila jumlah subyek nya besar maka jumlah sampel yang diambil adalah antara $10-15 \%$ atau $20-25 \%$, dalam penelitian ini diambil $21 \%$ dari jumlah populasi dengan teknik pengambilan sampel yang digunakan adalah kuota sampling, yaitu pengambilan sampel dari populasi dilakukan dengan jumlah (kuota) yang diinginkan.

\section{Instrumen Penelitian}

Kecerdasan emosi merupakan kemampuan yang dimiliki oleh individu untuk mengenali emosi diri (Self Awareness), mengelola emosi diri (Motivating Ownself), memotivasi diri (Motivating Ownself), mengenali emoasi orang lain (Emphaty), dan membina hubungan atau keterampilan sosial (Social Skills). 
Pengukuran kecerdasan emosi menggunakan skala kecerdasan emosi yang terdiri dari 40 aitem jenis skala likert, guna mendapatkan koefisien Validitas dan nilai Reliabilitas maka skala diuji cobakan pada remaja berjumlah 80 responden.

Untuk mengukur validitas Skala Kecerdasan Emosi Remaja digunakan perhitungan yang menggunakan rumus kolerasi Product Moment Person diperoleh 25 aitem akan tetapi yang diambil untuk penelitian setelah uji coba adalah 20 aitem yang hasilnya lebih besar yang berkisar antara 0,3307 sampai 0,6120 .

Untuk perhitungan uji reliabilitas peneliti menggunakan rumus Analisis Varians Hoyt diperoleh rxx' sebesar 0,7391 dengan demikian skala kecerdasan emosi dinyatakan reliabel/reliabilitasnya tinggi.

Persepsi anak terhadap kedekatan orang tua merupakan tanggapan anak terhadap kedekatan yang diberikan oleh orang tua melalui sentuhan lembut pada bagian tubuh anak, menjadikan anak sebagai teman, memberikan dorongan semangat, menanamkan rasa percaya diri, menyeru dengan lemah lembut, menghargai dan mengerti keberadaan anak.

Pengukuran persepsi anak terhadap kedekatan orang tua menggunakan skala yang terdiri dari 40 aitem jenis skala likert, guna mendapatkan koefisien Validitas dan nilai Reliabilitas maka skala diuji cobakan pada remaja berjumlah 80 responden.

Untuk mengukur validitas skala persepsi anak terhadap kedekatan orang tua digunakan perhitungan kolerasi Product Moment Person diperoleh 25 aitem akan tetapi yang diambil untuk penelitian setelah uji coba adalah 20 item yang hasilnya lebih besar yang berkisar antara 0,3726 sampai 0,5912 .

Untuk perhitungan uji reliabilitas peneliti menggunakan rumus Analisis Varians Hoyt diperoleh rxx' sebesar 0,8307 dengan demikian skala persepsi anak terhadap kedekatan orang tua dinyatakan reliabel/reliabilitasnya tinggi. 
Tabel 1.

Perincian jenis kelamin

\begin{tabular}{cccc}
\hline No & Jenis Kelamin & Jumlah & Prosentase (\%) \\
\hline $\mathbf{1}$ & Laki-laki & 43 siswa & $43 \%$ \\
\hline $\mathbf{2}$ & Perempuan & 57 siswa & $57 \%$ \\
\hline & Jumlah & 100 siswa & $100 \%$ \\
\hline
\end{tabular}

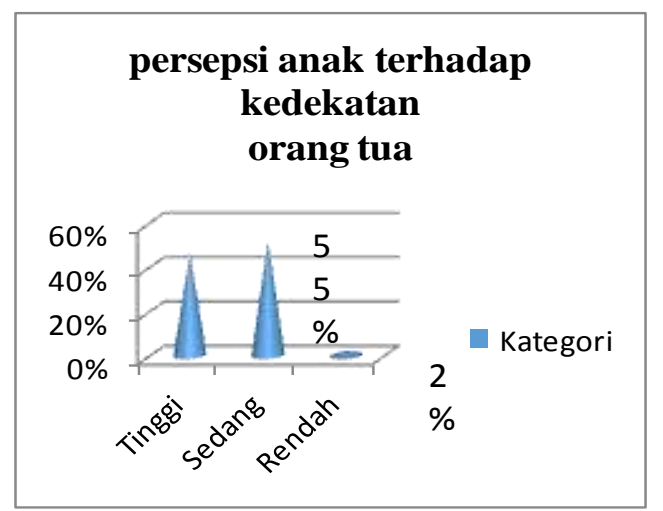

Gambar 1. Grafik persepsi anak terhadap kedekatan orang tua

Data yang diperoleh kemudian dianalisis dengan menggunakan Analisis Regresi Satu Prediktor.

\section{Hasil}

Dalam penelitian ini, jumlah subyek penelitian atau yang digunakan oleh peneliti sebanyak 100 remaja. Hal tersebut dapat terlihat dari data grafik pada tabel 1 diatas yang menunjukkan bahwa presentase jenis kelamin remaja laki-laki $43 \%$, dan remaja perempuan $57 \%$.

Berdasarkan perhitungan skor standar yang dilakukan oleh peneliti untuk skala persepsi anak terhadap kedekatan orang tua, diperoleh ringkasan seperti pada gambar 1.

Dari data grafik diatas dapat diketahui bahwa dari 100 remaja yang memiliki persepsi positif terhadap kedekatan orang tua tergolong tinggi sebanyak $43 \%$ remaja, yang tergolong sedang sebanyak 55\% remaja, dan yang rendah sebanyak 2\% remaja. Dengan demikian persepsi positif anak terhadap kedekatan orangtua pada remaja tergolong sedang.

Berdasarkan perhitungan skor standar yang dilakukan peneliti untuk 
skala kecerdasan emosi remaja, berikut ringkasan hasil yang dapat diperoleh sebagai berikut:

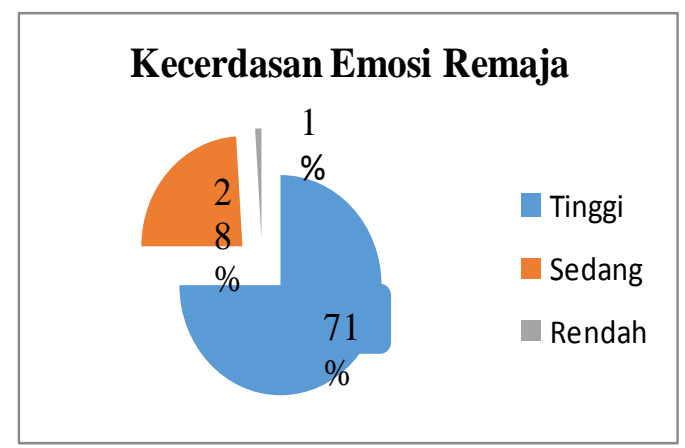

Gambar 2.

Grafik kecerdasan emosi remaja

Dari data grafik 2. diatas dapat diketahui bahwa dari 100 remaja di
SMP Negeri 2 Sukorejo yang memiliki kecerdasan emosi tinggi sebanyak $71 \%$ remaja, yang tergolong sedang sebanyak $28 \%$ remaja, dan yang rendah sebanyak $1 \%$ remaja. Dengan demikian hasil penelitian menunjukkan bahwa kecerdasan emosi remaja di SMP Negeri 2 tergolong tinggi.

Dari hasil penelitian, diperoleh hasil dari perhitungan statistik koefisien kolerasi pada tabel berikut ini:

Tabel 2.

Perhitungan Koefisien Korelasi Product Moment dengan Rumus Kasar

\begin{tabular}{|c|c|c|c|c|c|c|c|}
\hline \multirow{2}{*}{$\Sigma$} & $X Y$ & $X^{2}$ & $\mathbf{Y}^{2}$ & $\mathbf{r}_{\mathrm{xy}}$ & $R^{2} x y$ & $\mathrm{r}$-tabel $5 \%$ & $\mathrm{r}$-tabel $1 \%$ \\
\hline & $2.860,56$ & $9.747,56$ & $5.229,56$ & 0,40065 & $16,052 \%$ & 0,195 & 0,256 \\
\hline
\end{tabular}

* Sangat Signifikan

Dari hasil uji kolerasi diperoleh nilai $\mathrm{r}_{\mathrm{xy}}$ sebesar 0,4007 sedangkan pada taraf signifikan F-tab 1\% memenuhi nilai 0,256 maka ada kolerasi yang sangat signifikan antara persepsi anak terhadap kedekatan orang tua dengan kecerdasan emosi remaja, sehingga hal tersebut membuktikan bahwa semakin positif persepsi anak terhadap kedekatan orang tua maka semakin tinggi kecerdasan emosi yang dimiliki oleh remaja. Sebaliknya semakin negatif persepsi anak terhadap kedekatan orang tua maka semakin rendah kecerdasan emosi yang dimiliki oleh remaja. 
Tabel 3.

Ringkasan analisis Regresi Satu Prediktor

\begin{tabular}{cccccc}
\hline Sumber Variasi & Db & JK & RK/MK & Freg & $\begin{array}{c}\text { F-tab 1\% } \\
\text { F-tab 5\% }\end{array}$ \\
\hline Regresi (reg) & 1 & 839,7315 & 839,7315 & \multirow{2}{*}{18,7464} & 6,63 \\
Residu (res) & 98 & $4.389,8285$ & 44,7942 & - & - \\
\hline Total & 99 & $5.229,56$ & - & -84 \\
\hline
\end{tabular}

* Sangat signifikan

Dari perhitungan analisa regresi satu prediktor diperoleh Freg sebesar 18,7464 dengan $\mathrm{db} \quad 1$ lawan 98 diperoleh F- tab 5\% sebesar 3,84 dan Ftab $1 \%$ sebesar 6,63. Jadi hasilnya adalah sangat siginifikan. Artinya ada kolerasi antara persepsi anak terhadap kedekatan orang tua dengan kecerdasan emosi remaja. Dengan demikian persepsi anak terhadap kedekatan orang tua dapat digunakan untuk meramalkan kecerdasan emosi yang dimiliki remaja. Hal tersebut dapat dilihat dari koefisien determinan sebesar 16,05\%, yang berarti bahwa persepsi anak terhadap kedekatan orang tua memberikan sumbangan terhadap kecerdasan emosi yang dimiliki remaja sebesar 16,05\%, sedangkan $83,95 \%$ lainya adalah pengaruh dari faktor lain.

\section{Diskusi}

Hasil dari penelitian dapat diketahui bahwa hipotesis dalam penelitian ini yang menyatakan "ada hubungan antara persepsi anak terhadap kedekatan orang tua dengan kecerdasan emosi yang dimiliki remaja di SMP Negeri 2 Sukorejo" diterima. Hal tersebut sesuai dengan pendapat Goleman (2016) mengemukakan pendapat mengenai faktor-faktor yang dapat mempengaruhi perkembangan kecerdasan emosi remaja salah satunya adalah lingkungan keluarga. Lingkungan keluarga merupakan tempat pendidikan pertama bagi seorang anak dalam mempelajari emosi, dan hal ini dapat berkembang hingga individu beranjak dewasa, lingkungan keluarga yang sangat dekat dengan anak merupakan orang tua. Anak mengidentifikasi perilaku orang tua kemudian diinternalisasikan 
akhirnya menjadi bagian dalam kepribadian anak. Kehidupan emosi yang dibangun di dalam keluarga sangat berguna bagi anak kelak, bagaimana anak dapat cerdas secara emosional.

Berdasarkan paparan Edward R. Christopherson, (dalam Kurasi, 2015) sebuah pelukan jauh lebih efektif dari pada pujian atau ucapan sayang karena membuat anak merasa dicintai dan dihargai. Dalam hal ini apabila orangtua dapat menciptakan kedekatan dengan memberikan pelukan terhadap anak-anaknya hal tersebut akan menjadikan anak merasa dicintai dan dihargai sehingga hal tersebut dapat berdampak positif terhadap persepsinya mengenai kedekatan orang tuanya, sehingga berdampak baik pada kecerdasan emosinya, seperti menjadi lebih mampu mengendalikan emosinya saat menghadapi kesulitan atau masalah. hal tersebut didukung oleh pendapat Rahmad, 2001 (dalam Fatimah, 2010) persepsi terhadap perilaku atau kedekatan orang tua merupakan cara pandang anak terhadap bentuk kedekatan orang tua yang diterimanya, sehingga apabila seorang anak yang mempersepsikan kedekatan orang tuanya secara positif menurut pengalaman yang diterima anak, maka hal ini cenderung dapat menciptakan kecerdasan emosi yang tinggi. Sehingga dalam hal ini, persepsi anak terhadap kedekatan orang tuanya juga merupakan salah satu faktor yang bisa mempengaruhi kecerdasan emosi.

Dalam sebuah penelitian juga mengatakan bahwa kedekatan orang tua dan anak dapat mempengaruhi perkembangan mental anak yakni persepsi anak terhadap pola kedekatan orang tuanya, hal ini didukung dari sebuah penelitian yang menunjukkan bahwa melalui rangsangan langsung seperti membelai, mengajak bicara, dan bermain pada anak yang dilakukan orang tua dapat merangsang persepsi anak terhadap pengetahuan sosialnya, dalam artian yang lebih jelas, bahwa persepsi anak terhadap kedekatan orang tua yang positif mampu memberikan sumbangan nilai positif terhadap kecerdasan emosi anak menjadikan lebih percaya diri, memiliki rasa empati dan mudah bersosialisasi. Sehingga persepsi anak mengenai kedekatan orang tua 
memiliki sumbangan terhadap kecerdasan emosi remaja.

Dari perhitungan analisa regresi satu prediktor diperoleh Freg sebesar 18,7464 dengan $\mathrm{db} \quad 1$ lawan 98 diperoleh F- tab 5\% sebesar 3,84 dan Ftab $1 \%$ sebesar 6,63. Jadi hasilnya adalah sangat siginifikan. Artinya ada kolerasi antara persepsi anak terhadap kedekatan orang tua dengan kecerdasan emosi remaja. Dengan demikian persepsi anak terhadap kedekatan orang tua dapat digunakan untuk meramalkan kecerdasan emosi yang dimiliki remaja.

Hal tersebut dapat dilihat dari koefisien determinan sebesar 16,05\%, yang berarti bahwa persepsi anak terhadap kedekatan orang tua memberikan sumbangan terhadap kecerdasan emosi yang dimiliki remaja sebesar $16,05 \%$, sedangkan $83,95 \%$ lainya adalah pengaruh dari faktor lain seperti konsep diri, teman sebaya, atau lingkungan sekolah serta aktivitas lain diluar lingkungan keluarga.

\section{Kesimpulan}

Dari hasil penelitian yang telah dilakukan dapat ditarik kesimpulan bahwa ada hubungan yang sangat signifikan antara persepsi anak terhadap kedekatan orang tua dengan kecerdasan emosi pada remaja. Artinya ada kolerasi antara persepsi anak terhadap kedekatan orang tua dengan kecerdasan emosi remaja, sehingga hal tersebut membuktikan bahwa semakin positif persepsi anak terhadap kedekatan orang tua maka semakin tinggi kecerdasan emosi yang dimiliki oleh remaja. Sebaliknya semakin negatif persepsi anak terhadap kedekatan orang tua maka semakin rendah kecerdasan emosi yang dimiliki oleh remaja.

Dengan demikian persepsi anak terhadap kedekatan orang tua dapat digunakan untuk meramalkan kecerdasan emosi yang dimiliki remaja. Hal ini sesuai dengan hasil perhitungan korelasi determinan yang memberikan sumbangan $16,05 \%$. Hubungan tersebut hanya memberikan sekian persen karena 83,95\% kemungkinan lainya adalah pengaruh dari faktor lain.

Adapaun faktor lain yang kemungkinan memberikan pengaruh besar terhadap kecerdasan emosi remaja, misalnya: konsep diri (Self 
concept), lingkungan sekolah, lingkungan teman sebaya, beserta aktivitas-aktivitas yang dilakukannya dalam kehidupan sehari-hari, dan lainlain. Dengan demikian hipotesa yang menyatakan bahwa ada hubungan mengenai persepsi anak terhadap kedekatan orang tua dengan kecerdasan emosi yang dimiliki remaja" diterima.

\section{Saran}

Mengingat hasil penelitian telah mengungkapkan mengenai faktor yang berpengaruh terhadap kecerdasan emosi pada remaja adalah persepsi anak terhadap kedekatan orang tua, maka disarankan kepada:

1. Remaja

Dalam hal ini di sarankan bagi remaja untuk lebih memperhatikan faktor-faktor yang mempengaruhi terbangunnya kecerdasan emosi pada remaja, sehingga dapat memilah-milah faktor apa saja yang dapat meningkatkan kecerdasan emosi.

2. Orang tua

Bagi orang tua untuk menciptakan kedekatan antara anak dengan orangtuanya hendaknya orangtua mampu memberikan sikap yang baik untuk merespon anak seperti halnya: memberikan kebebasan pada anak namun tetap terjalin komunikasi yang intensif, memberikan rasa aman pada anak seperti memberkan pelukan/ cium pipi kanan kiri/cium dikening, menghargai anak seperti memberikan pujian, mendengarkan pendapat anak, menjadikan anak sebagai teman dll. Stimulus yang diberikan orang tua seperti halnya kedekatan tersebut, dapat mempengaruhi persepsi yang muncul terhadap diri anak mengenai orang tuanya, sehingga anak cenderung menginterpretasikan orang tua mereka sesuai dengan perlakuan yang diberikan oleh orang tua terhadap anak. Untuk meningkatkan kecerdasan emosi pada remaja, beberapa saran yang diberikan peneliti dapat membantu remaja memiliki persepsi positif terhadap orangtuanya sehingga mampu meningkatkan kecerdasan emosi pada remaja.

\section{Referensi}

Asyava, T. S. (2011). Hubungan attachment terhadap Ayah dengan kecerdasan Emosi pada Remaja Laki-Laki. Medan: Universitas SumateraUtara. Retrivied from: 
http://repository.usu.ac.id/bitstrea m/123456789/23209/7.pdf

Epa, T. N. (2013). Peran Ayah Sama Dengan Peran Ibu?. Artikel Kesehatan Umum. Retrivied From:

http://www.taranatureepa.co.id/p eran-ayah-sama-dengan-peranibu

Charis, A. (2013). Persepsi Siswa Akan Fungsi Guru Bimbingan dan Konseling (BK)Terhadap Motivasi Berkonsultasi Di MTS Miftahul Ulum Mojokerto [Skripsi]. Pasuruan: Universitas Yudarta Pasuruan.

Fatimah, L. (2010). Hubungan Persepsi Anak Terhadap Keharmonisan Keluarga dan Pola Asuh Orang Tua Dengan Motivasi Belajar. (Online). Diakses Januari 2016.

Goleman, D. (2016). Kecerdasan Emosional. Jakarta: PT. Gramedia Pustaka Utama

Goleman, D. (2014). Emotional Intelligence. Jakarta: PT Gramedia Pustaka Utama.

Hermasanti, W. K. (2009). Pengaruh Pola Kelekatan dengan Kecerdasan Emosi Remaja. Surakarta: Universitas Sebelas Maret. Retrivied From: http://core.ac.uk/download/files/4 78/12346778.pdf

Jahja, Y. (2011). Psikologi Perkembangan. Jakarta: Kencana.

Kurasi, (2015). 7 Hal yang Harus Orang Tua Ketahui Tentang Pelukan Pada Anak. Sayangianak.com. Retrivied from:

http://www.9detik.co/2015/07/7-

hal-yang-harus-orang-tua-

ketahui.html

Safitri, Y. (2012). Hubungan Antara Persepsi Pola Asuh Demokratis Dengan Pemilihan Karir Pada Siswa Kelas XI SMA Negeri 11 Yogyakarta [Skripsi]. Yogyakarta: Universitas Negeri Yogyakarta.

Sholikah, M. (2011). Kedekatan Orang Tua Dengan Anak Pengaruhnya Terhadap Motivasi Belajar Siswa Madrasah Ibtidaiyah Ma'arif Grabag 2 Magelang Tahun 2011/1012 [Skripsi]. Salatiga: Sekolah Tinggi Agama Islam Negeri.

Tanjung, M. A. (2015). Pem-bully dari SMPN 4 Binjai dari Keluarga Broken Home. Tribunnews.com. Retrivied from: http://medan.tribunnews.com/201 5/09/07/pem-bully-dari-smpn-4binjai-dari-keluarga-broken-home 